\title{
Growing-season moisture variability in the eastern USA during the last 800 years
}

\author{
Steven M. Quiring* \\ Center for Climatic Research and Department of Geography, 211 Pearson Hall, University of Delaware, Newark, \\ Delaware 19716, USA
}

\begin{abstract}
An 800 yr tree-ring-based reconstruction of the Palmer Hydrological Drought Index was used to document the frequency, severity, and duration of growing-season moisture anomalies (both wet and dry events) in the southern mid-Atlantic region of the USA. The data indicate that this region has experienced significant growing-season moisture variability (interannual to multidecadal) since A.D. 1185. Conditions during the 18th century were much wetter than they are today, and the droughts that occurred during the 16th century tended to be both longer and more severe. The recent growing-season moisture anomalies that occurred during 2002 and 2003 can only be considered rare events if they are evaluated with respect to the relatively short instrumental record (1895 to 2003). When compared to the 800 yr reconstructed record, neither of these events is particularly unusual. Growing-season moisture conditions during the 20th century appear to be well within the range of natural climate variability when compared to the 800 yr record.
\end{abstract}

KEY WORDS: Drought · Palmer Drought Severity Index $\cdot$ Palmer Hydrological Drought Index $\cdot$ Tree rings $\cdot$ North Carolina $\cdot$ Virginia

Resale or republication not permitted without written consent of the publisher

\section{INTRODUCTION}

Drought is a naturally recurring climatic phenomenon that has a significant impact on both the environment and society (Stahle et al. 1998, 2000, deMenocal 2001). This is evident when the effects of the 2001 to 2002 drought on the eastern USA are examined. Severe drought began to take hold in the eastern USA during the fall and winter of 2001, and it continued to intensify through the spring and summer of 2002 (Fig. 1). By June of 2002, anomalously dry conditions were present along the entire East Coast from Massachusetts to northern Florida, and severe drought conditions were affecting an area stretching from New Jersey to northern Florida. In response, 13 states were forced to ration water (Watson \& Overberg 2002), a state of drought emergency was declared in eastern Pennsylvania and throughout New Jersey, and drought warnings were issued in New York City and central and eastern counties in Maryland (Mont- gomery 2002). Connecticut, Delaware, New Jersey, Virginia, and Massachusetts all experienced their driest September (2001) to February (2002) period since the beginning of the instrumental record (NOAA 2002).

Drought conditions finally began to ease in October of 2002 and anomalously wet conditions persisted for approximately a year (October 2002 to October 2003). The growing-season moisture conditions in 2003 rank as the wettest observed since the beginning of the instrumental record. The recent occurrence of these 2 extreme growing-season moisture anomalies raises some interesting questions: Are moisture conditions in this region becoming more variable? How often can we expect moisture anomalies of this severity to occur?

Unfortunately, instrumental records are only available for about the last $100 \mathrm{yr}$, not long enough to document the entire range of natural variability within the climate system, particularly for multidecadal- to century-scale (low frequency) variability (deMenocal 


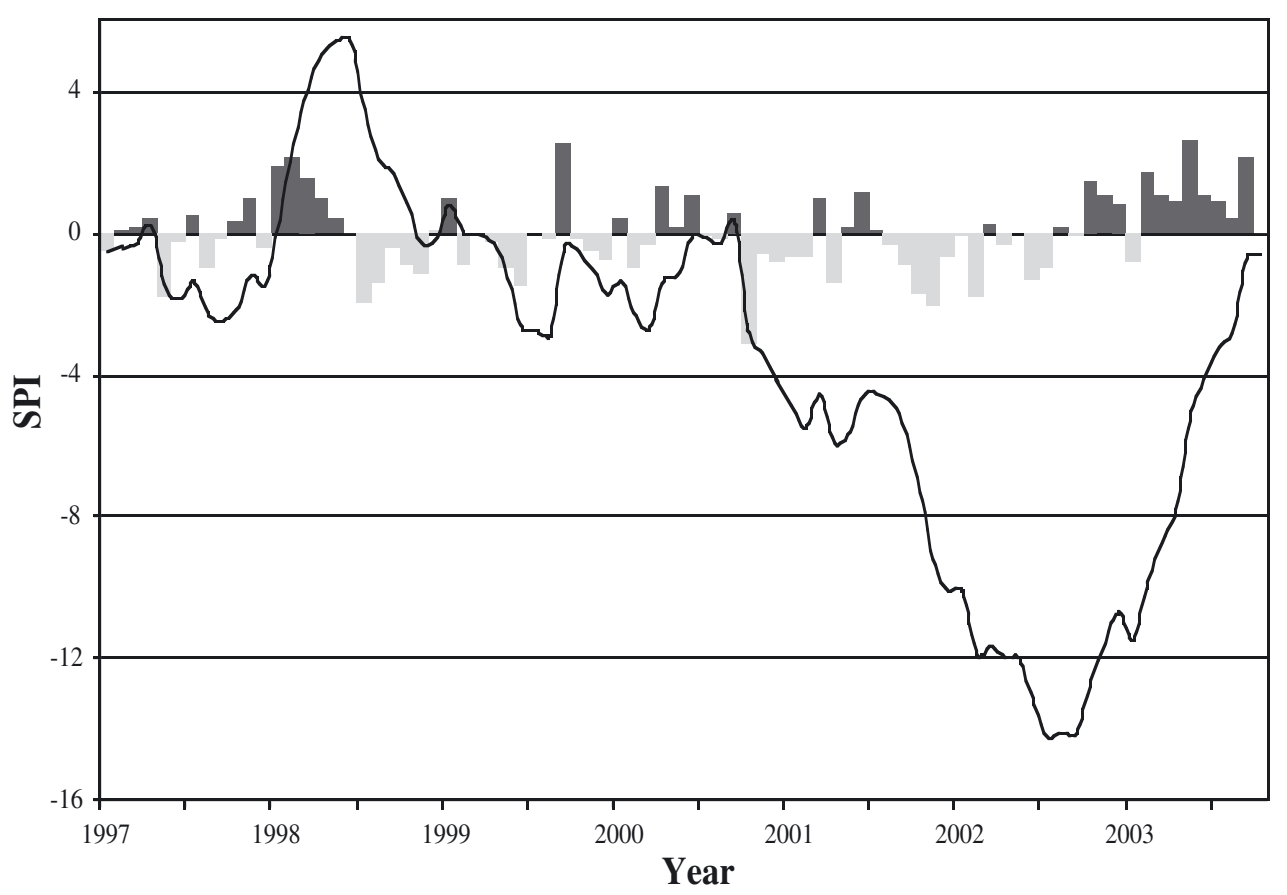

Fig. 1. Monthly precipitation anomalies (January 1997 to October 2003) shown for a representative climate division within the study region (VA2). Both the monthly Standardized Precipitation Index (SPI) values (bars) and the cumulative SPI (line) are shown

2001). Paleoclimate reconstructions suggest that droughts in the 16th century exceeded the severity, duration, and spatial extent of droughts witnessed during the period of instrumental record, and thus have been titled 'megadroughts' (Woodhouse \& Overpeck 1998, Stahle et al. 2000). During the second half of the 16th century, these severe drought conditions dominated much of the continental USA. In the eastern states drought conditions were particularly severe during the 1560s (1559 to 1569) and 1580s to $1590 \mathrm{~s}$ (Stahle et al. 2000). There is also evidence that, prior to A.D. 1200, extreme and large-scale droughts occurred more frequently and were more persistent than during any time since (Laird et al. 1996).

Tree-ring-based reconstructions of past climates have been used for the following: (1) to explain the disappearance of the buffalo herd (Woodhouse et al. 2002) and the collapse of civilizations (deMenocal 2001); (2) to search for analogues of 20th century drought (moisture) patterns (Fye et al. 2003); (3) to investigate the temporal patterns of drought recurrence (periodicities) (Stockton \& Meko 1983, Cook et al. 1997); (4) and to reconstruct the magnitude, severity, and spatial extent of growing-season drought events (Woodhouse \& Overpeck 1998, Cook et al. 1999, Stahle et al. 2000). The majority of these tree-ring studies have focused on the central and western USA because an abundance of suitable tree-ring data exists and the relationship between tree rings and climate is quite direct. At least 2 recent studies have focused on reconstructing growing-season moisture conditions in the eastern USA (Stahle et al. 1998, Druckenbrod et al. 2003).

Stahle et al. (1998) reconstructed the growing-season moisture conditions for the Tidewater region of Virginia and North Carolina from A.D. 1185 to 1984. They found that this region has experienced substantial inter-annual and decadal variability in growingseason moisture conditions. In particular, the authors found that the period from 1587 to 1589, which coincides with the settlement of the Roanoke ('Lost') Colony, was the driest 3 yr interval in the last $800 \mathrm{yr}$. The Jamestown Colonists also had the misfortune to arrive in April 1607, during the driest 7 yr period (1606 to 1612) in 770 yr (Stahle et al. 1998).

Druckenbrod et al. (2003) used tree-ring data to reconstruct precipitation at James Madison's Montpelier plantation in Virginia. They discovered a significant shift in the timing of the maximum growingseason precipitation since the beginning of the record in 1784. The data suggest that the peak in growingseason precipitation now occurs about 1 mo later than it did during Madison's era (Druckenbrod et al. 2003).

In this study, we use the reconstruction of Stahle et al. (1998) to examine the last $800 \mathrm{yr}$ of growing-season moisture variability in the southern mid-Altantic region 
Table 1. Proxy data used to analyze growing-season moisture conditions in the southern mid-Atlantic region of the USA

\begin{tabular}{|c|c|c|c|c|c|}
\hline Reconstructior & Location & Years & Calibration $\left(\mathrm{r}^{2}\right)$ & Verification $\left(\mathrm{r}^{2}\right)$ & Source \\
\hline July PHDI & 4 climate divisions ( 2 in Virginia and 2 in North Carolina) & 1185-1984 & 1941-1984 (0.44) & 1896-1940 (0.31) & Stahle et al. (1998) \\
\hline
\end{tabular}

of the USA. In particular, this reconstruction is used to document the frequency, severity, and duration of severe growing-season moisture anomalies (both wet and dry events). This baseline climatology provides a means of determining whether growing-season moisture conditions in the 20th century represent the range of natural variability within the climate system. The recent growing-season moisture anomalies (e.g. extremely dry conditions in 2002 and the extremely wet conditions in 2003) are also compared against the reconstructed record to place these events in historical context.

\section{DATA AND METHODS}

\subsection{Characterizing growing-season moisture conditions}

Drought indices are commonly used to quantify moisture conditions within a region, to detect the onset and to measure the severity and spatial extent of drought events (Alley 1984). This study utilizes 2 closely related drought indices, the Palmer Drought Severity Index (PDSI) and the Palmer Hydrological Drought Index (PHDI). Both the PDSI and PHDI were developed by Palmer (1965) and they are calculated using a soil moisture/water balance algorithm that measures how moisture conditions in a given month compare with the normal or climatically appropriate moisture conditions for that month. A positive (negative) PDSI or PHDI indicates that conditions are wetter (drier) than normal (Palmer 1965). The only difference between the 2 indices is their response time. The PDSI was designed to represent meteorological drought conditions; therefore, it responds more quickly to changes in moisture conditions. The PHDI was designed to represent hydrological drought conditions and responds more slowly to changes in moisture conditions. A number of authors have written detailed descriptions of how the Palmer indices are calculated and have discussed their limitations (Alley 1984, Karl 1986, Guttman 1998, Heim 2002).

Tree rings are an excellent proxy for the PDSI or PHDI because they can be precisely dated to a specific year and they are highly correlated with growing-season moisture conditions. In addition, the growing-season value of the PDSI or PHDI integrates both current (summer) and antecedent (spring and winter) temper- ature and precipitation anomalies (Fye et al. 2003). While the tree-ring-based reconstructions of the PDSI or PHDI are useful for determining the relative strength, timing, and duration of moisture anomalies, they underestimate the actual severity of each event (i.e. they are a conservative measure of severity) (Fye et al. 2003). It has been demonstrated that reconstructed PDSI values are generally about 1 class less severe than observed PDSI values (Woodhouse \& Overpeck 1998).

\subsection{Data}

An 800 yr reconstruction (1185 to 1984) of July PHDI for 2 climate divisions in Virginia (VA1 and VA2) and 2 in North Carolina (NC7 and NC8) was acquired from the World Data Center For Paleoclimatology in Boulder, $\mathrm{CO}$ (the reconstructed July PHDI is available at: ftp://ftp.ngdc.noaa.gov/paleo/treering/reconstructions/ jamestown-roanoke/). The reconstruction is based on 2 long bald cypress Taxodium distichum (L.) Rich. chronologies (Stahle et al. 1998) (Table 1 \& Fig. 2). According to Stahle et al. (1998), the results of the verification indicate that this tree-ring reconstruction provides a reasonable approximation of actual conditions, and these findings are also supported by documentary evidence from the early colonial period.

Monthly precipitation and PHDI data were acquired for the period 1895 to 2003 from the National Climatic Data Center (NCDC) for 2 climate divisions in Virginia (VA1 and VA2) and 2 in North Carolina (NC7 and NC8) (Fig. 2). The July PHDI data from the 4 climate divisions were spatially averaged to form a single regional indicator of growing-season moisture variability during the instrumental period.

\section{RESULTS AND DISCUSSION}

Tree-ring-based reconstructions of drought indices (such as the PHDI) tend to be conservative estimates of moisture conditions (they are less extreme and less variable). Therefore, the instrumental PHDI has a higher standard deviation and variance than the reconstructed PHDI. The reconstructed PHDI statistics are also based on a much larger sample $(n=800)$ than the instrumental PHDI statistics $(n=109)$. One method 


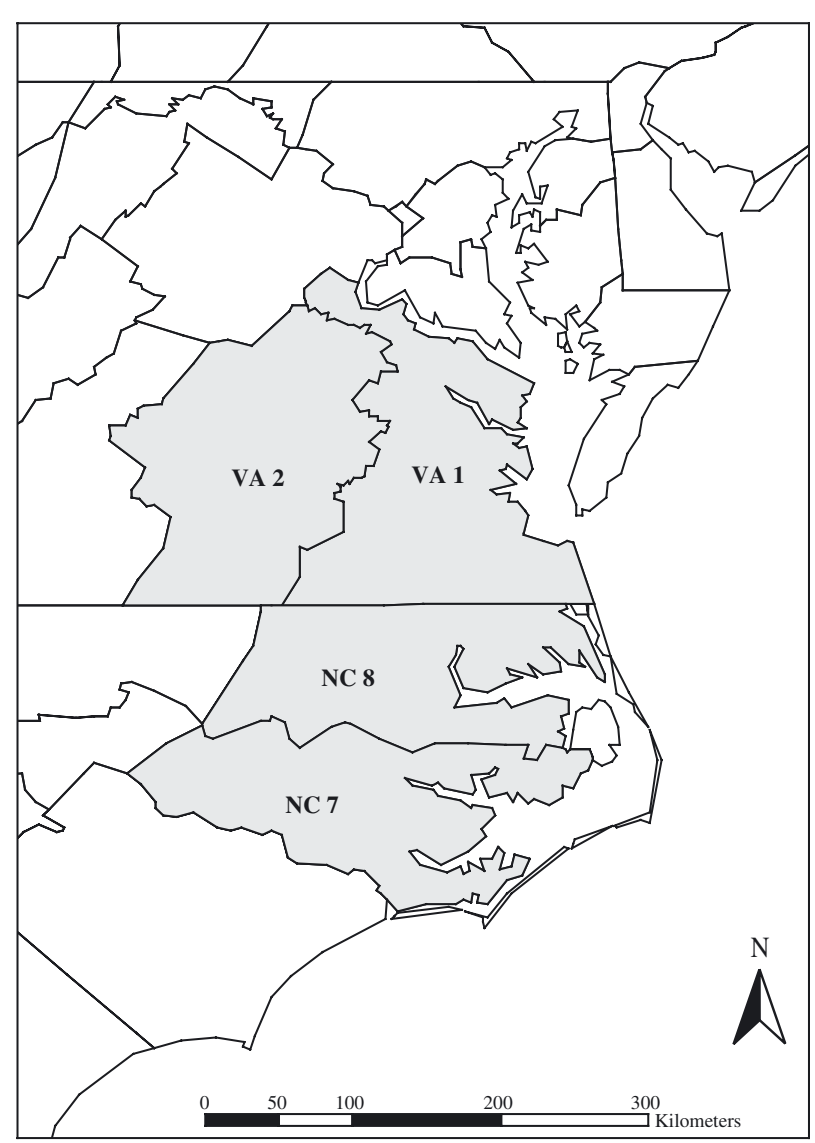

Fig. 2. Location of proxy and instrumental data sources: Stahle et al. (1998) regional PHDI reconstructions and instrumental data (shaded climate divisions)

to make the 2 datasets more comparable is to standardize them (Table 2). However, even when the 2 datasets are standardized, comparisons should be carried out cautiously since tree growth is a function of more than just temperature and precipitation. As a result, the instrumental and reconstructed PHDI will not be the same, even under identical climatic condi-

Table 2. Descriptive statistics for the instrumental (1895 to 2003) and reconstructed (1185 to 1984) July PHDI and the standardized version of both datasets. $(\mathrm{SD}=$ standard deviation, low $=$ lowest value observed, high $=$ highest value observed)

\begin{tabular}{|lcccc|}
\hline & $\begin{array}{c}\text { Instrumental } \\
(1895-2003)\end{array}$ & $\begin{array}{r}\text { Standardized } \\
\text { instrumental } \\
(1895-2003)\end{array}$ & $\begin{array}{c}\text { Reconstructed } \\
(1185-1984)\end{array}$ & $\begin{array}{r}\text { Standardized } \\
\text { reconstructed } \\
(1185-1984)\end{array}$ \\
\hline Mean & 0.18 & 0.00 & 0.18 & 0.00 \\
Median & 0.19 & 0.01 & 0.08 & -0.07 \\
SD & 1.79 & 1.00 & 1.36 & 1.00 \\
Low & -4.20 & -2.45 & -3.21 & -2.49 \\
High & 4.15 & 2.22 & 5.31 & 3.77 \\
\hline
\end{tabular}

Table 3. Summary of July PHDI frequency statistics from the standardized reconstructed (1185 to 1984) data

\begin{tabular}{|crcc|}
\hline & Count & $\begin{array}{c}\text { Frequency } \\
(\%)\end{array}$ & $\begin{array}{c}\text { Return } \\
\text { period (yr) }\end{array}$ \\
\hline 3 to 4 & 3 & 0.38 & 266.7 \\
2 to 3 & 23 & 2.88 & 34.8 \\
1 to 2 & 95 & 11.88 & 8.4 \\
-1 to 1 & 551 & 68.88 & 1.5 \\
-1 to -2 & 119 & 14.88 & 6.7 \\
-2 to -3 & 9 & 1.13 & 88.9 \\
-3 to -4 & 0 & 0.00 & - \\
\hline
\end{tabular}

tions. For example, the standardized PHDI value for 1942 in the instrumental record is -2.45 , while the same value is -1.90 in the reconstructed record.

\subsection{Frequency}

The frequency of anomalously wet and dry events was determined by sorting the standardized reconstructed PHDI into categories and counting the number of events that fell within each category (Table 3 ). Approximately $69 \%$ of the growing seasons had a moisture condition that is within \pm 1 SD of the mean (near normal). There were 128 growing seasons with a PHDI value of less than -1 , accounting for $16 \%$ of the record. Therefore, anomalously dry growing seasons have a return period of approximately $6.3 \mathrm{yr}$. There were 121 growing seasons with a PHDI value of greater than +1 , accounting for $15 \%$ of the record. Therefore, anomalously wet growing seasons have a return period of approximately $6.6 \mathrm{yr}$. While the total number of anomalously wet and dry events was similar, there were more extremely wet events (PHDI +3 to +4 ) than extremely dry events (PHDI -3 to -4 ). Only 9 anomalously dry events had a growing season PHDI of less than -2 (and none had a value of less than -3 ), but there were 26 wet events that had a PHDI of greater than +2 (and 3 that had a value greater than +3$)$.

\subsection{Severity}

The growing season of 1587 was the driest during the last $800 \mathrm{yr}$ (PHDI = -3.21) (Table 4). The second driest growing season occurred in 1211 $(\mathrm{PHDI}=-3.03)$. These 2 extreme droughts stand out because of their severity, while the remaining 8 droughts have relatively similar PHDI 
Table 4. The 10 most severe growing-season dry and wet events between 1185 to 1984 based on the reconstructed PHDI

\begin{tabular}{|cccc|}
\hline & \multirow{2}{*}{ Dry } & \multicolumn{2}{c|}{ Wet } \\
Year & Severity & Year & Severity \\
\hline 1587 & -3.21 & 1424 & 5.31 \\
1211 & -3.03 & 1702 & 4.66 \\
1401 & -2.84 & 1753 & 4.48 \\
1455 & -2.76 & 1796 & 4.14 \\
1324 & -2.74 & 1415 & 3.92 \\
1765 & -2.74 & 1341 & 3.87 \\
1638 & -2.67 & 1196 & 3.84 \\
1837 & -2.56 & 1754 & 3.81 \\
1806 & -2.55 & 1724 & 3.74 \\
1372 & -2.53 & 1886 & 3.60 \\
& & & \\
\hline
\end{tabular}

Table 5. The 10 most severe growing-season dry and wet events between 1895 to 2003 based on the instrumental PHDI

\begin{tabular}{|lccc|}
\hline & \multirow{2}{*}{ Dry } & \multicolumn{2}{c|}{ Wet } \\
\hline Year & Severity & Year & Severity \\
\hline 1942 & -4.20 & 2003 & 4.16 \\
1986 & -3.67 & 1989 & 3.10 \\
2002 & -3.30 & 1984 & 2.96 \\
1932 & -2.91 & 1978 & 2.75 \\
1955 & -2.83 & 1938 & 2.69 \\
1985 & -2.69 & 1972 & 2.60 \\
1925 & -2.66 & 1901 & 2.59 \\
1911 & -2.47 & 1962 & 2.58 \\
1999 & -2.39 & 1979 & 2.46 \\
1926 & -2.38 & 1937 & 2.45 \\
& & & \\
\hline
\end{tabular}

values (Table 4). The list of the most severe droughts includes at least $1 \mathrm{yr}$ from each century covered by the reconstructed PHDI, with the exception of the 12th and 20th centuries. According to the reconstructed PHDI, the most severe growing-season drought during the period of overlap (1895 to 1984) occurred in 1942, and this event ranks 15 th on the drought severity list.

The wettest growing season occurred in 1424 $($ PHDI $=5.31)$, and this event was significantly more extreme than any other year since 1185 . Five of the 10 wettest years occurred during the 18th century, including the 2 consecutively wet years (1753 and 1754). None of the 10 wettest years occurred in the 16th, 17th, or 20th centuries. According to the reconstructed PHDI, the wettest year during the period of overlap (1895 to 1984) occurred in 1973 (PHDI = 3.26) and it ranks as the 21st wettest growing season since 1185 .

The 10 wettest and driest growing seasons were also examined using the instrumental PHDI (Table 5). The driest growing season since 1895 occurred in 1942 (PHDI $=-4.20)$. The reconstructed PHDI also identified this year as the driest growing season during the period of overlap. The second driest growing season occurred in 1986 (PHDI $=-3.67$ ), and the recent drought of 2002 ranks as the third driest growing season $($ PHDI $=-3.30$ ) between 1895 and 2003. Severe droughts occurred in consecutive years in 1925-1926 and 1985-1986. None of the 10 driest growing seasons occurred during the 1960s or 1970s.

According to the instrumental record, the wettest growing season on record occurred in 2003 (PHDI = 4.16). The wet conditions during 2003 provide a sharp contrast to the moisture conditions during 2002 and the difference in the PHDI values between 2002 and 2003 (7.46) represents the single largest change in moisture conditions between consecutive growing seasons during the instrumental record. Many of the wettest growing seasons occurred during the latter part of the 20th century. The 1970 s were a particularly wet decade; 1972, 1978, and 1979 all ranked in the top 10. The second and third wettest growing seasons occurred in $1989($ PHDI $=3.10)$ and $1984($ PHDI $=2.96)$ respectively. This highlights that the 1980s was a decade with a highly variable moisture regime: 2 years ranked in the top 10 driest and 2 years ranked in the top 10 wettest. It appears that the 1930s also had highly variable moisture conditions.

\subsection{Duration}

The durations of anomalously dry (wet) events were determined by counting the number of consecutive growing seasons that had a reconstructed July PHDI value of less than -1 (greater than +1 ) (Table 6 ). This is not a true measure of the duration of a moisture anomaly because only growing-season moisture conditions are considered. Therefore, it is possible that conditions could have been near normal or wetter than normal during the months between (fall, winter, spring) consecutive growing seasons.

Not surprisingly, the majority of anomalously wet $(75 \%)$ and dry $(71 \%)$ events persisted for only 1 or 2

Table 6 . The duration of anomalously wet (number of consecutive growing-seasons with a PHDI value of $>1.0$ ) and anomalously dry (number of consecutive growing-seasons with a PHDI value of $<-1.0$ ) events

\begin{tabular}{|lcc|}
\hline Duration & $\begin{array}{c}\text { Count of } \\
\text { dry events }\end{array}$ & $\begin{array}{c}\text { Count of } \\
\text { wet events }\end{array}$ \\
\hline 1 & 53 & 82 \\
2 & 25 & 34 \\
3 & 7 & 8 \\
4 & 3 & 5 \\
5 & 2 & 1 \\
\hline
\end{tabular}


consecutive growing seasons. Extended wet and dry events (at least $3 \mathrm{yr}$ ) have occurred more rarely in this region. Approximately $25 \%$ of anomalously wet growing seasons occurred during an extended wet event and $29 \%$ of anomalously dry growing seasons occurred during an extended dry event. A total of 12 drought events lasted at least 3 consecutive growing seasons between 1185 and 1984. Four 4 yr drought events occurred in 1209 to 1212,1435 to 1456 , and 1566 to 1569 , while seven 3 yr drought events occurred. In total, 2 instances of $5 \mathrm{yr}$ drought events have been recorded, the first from 1606 to 1610, which corresponds to the arrival of the Jamestown Colonists (Stahle et al. 1998), and the second from 1940 to 1944. Thirteen anomalously wet events occurred that persisted at least $3 \mathrm{yr}$. The longest wet event on record lasted for 5 yr (1339 to 1343). Five 4 yr wet events occurred in 1279 to 1282,1298 to 1301,1576 to 1579 , 1889 to 1892 , and 1972 to 1975 , while eight 3 -yr events occurred. Both the 4 yr wet event that occurred from 1972 to 1975 and the 5 yr dry event that occurred from 1940 to 1944 are also evident in the instrumental PHDI record.

\subsection{Are the moisture conditions observed during the 20th century normal?}

Climate models, run with a $2 \times \mathrm{CO}_{2}$ scenario, predict decreases in summer precipitation and soil moisture and significant increases in the frequency and duration of extreme droughts in the USA (Gregory et al. 1997, Voss et al. 2002). To determine whether a significant shift has occurred in the mean or variability of growing-season moisture conditions in the 20th century, the 800 yr PHDI reconstruction was divided into eight $100 \mathrm{yr}$ blocks (Table 7) and the last $100 \mathrm{yr}$ of the record were compared with earlier periods. Unfortunately, the reconstructed PHDI record ends in 1984 and, because of the difficulty in directly comparing the instrumental and reconstructed PHDI, the last 19 growing seasons were not included in the analysis.

The last 100 yr (1885 to 1984) were slightly wetter than normal. Only the period from 1685 to 1784 experienced moisture conditions that were significantly wetter than the last $100 \mathrm{yr}$. In addition to being wetter, the last 100 yr have also been slightly less variable than preceding centuries. The only period with a lower SD occurred between 1485 and 1584. In fact, when all of the statistics of 1885 to 1984 are compared with 1485 to 1584 , there is remarkable similarity. This suggests that the moisture regime of 1885 to 1984 may be similar to that of the late 15th and 16th centuries. Between 1885 and 1984, approximately normal numbers of severe wet and dry growing seasons occurred compared to previous centuries (similar to the overall mean) (Table 8).

Growing-season moisture conditions during the 20th century were also compared to past conditions by examining 20 yr mean PHDI values (Fig. 3). It is evident that there has been substantial multidecadal moisture variability in this region during the last

Table 7. Reconstructed July PHDI statistics summarized by century (1185 to 1984)

\begin{tabular}{|lrccccrrrr|}
\hline & $1185-1284$ & $1285-1384$ & $1385-1484$ & $1485-1584$ & $1585-1684$ & 1685-1784 & 1785-1884 & 1885-1984 & Mean \\
\hline Mean & 0.13 & 0.23 & 0.20 & 0.17 & -0.04 & 0.37 & 0.13 & 0.21 & 0.18 \\
Median & -0.22 & 0.06 & 0.18 & 0.11 & -0.06 & 0.38 & 0.01 & 0.16 & 0.08 \\
SD & 1.44 & 1.43 & 1.34 & 1.25 & 1.31 & 1.49 & 1.31 & 1.29 & 1.36 \\
Low & -3.03 & -2.74 & -2.84 & -2.19 & -3.21 & -2.73 & -2.56 & -2.41 & -2.71 \\
High & 3.84 & 3.87 & 5.31 & 3.51 & 3.48 & 4.66 & 4.14 & 3.60 & 4.05 \\
\hline
\end{tabular}

Table 8. Reconstructed July PHDI frequency summarized by century (1185 to 1984)

\begin{tabular}{|c|c|c|c|c|c|c|c|c|c|}
\hline & 1185-1284 & $1285-1384$ & 1385-1484 & $1485-1584$ & 1585-1684 & 1685-1784 & 1785-1884 & 1885-1984 & Mean \\
\hline$>4$ & 0 & 0 & 1 & 0 & 0 & 2 & 1 & 0 & 0.38 \\
\hline 3 to 4 & 4 & 5 & 1 & 2 & 1 & 4 & 1 & 3 & 2.63 \\
\hline 2 to 3 & 9 & 7 & 7 & 5 & 6 & 8 & 10 & 7 & 7.38 \\
\hline 1 to 2 & 13 & 19 & 16 & 19 & 14 & 14 & 7 & 13 & 14.38 \\
\hline-1 to 1 & 53 & 51 & 60 & 56 & 54 & 58 & 64 & 59 & 56.88 \\
\hline-1 to -2 & 17 & 12 & 11 & 17 & 18 & 10 & 14 & 16 & 14.38 \\
\hline-2 to -3 & 3 & 6 & 4 & 1 & 6 & 4 & 3 & 2 & 3.63 \\
\hline-3 to -4 & 1 & 0 & 0 & 0 & 1 & 0 & 0 & 0 & 0.25 \\
\hline$<-4$ & 0 & 0 & 0 & 0 & 0 & 0 & 0 & 0 & 0.00 \\
\hline
\end{tabular}




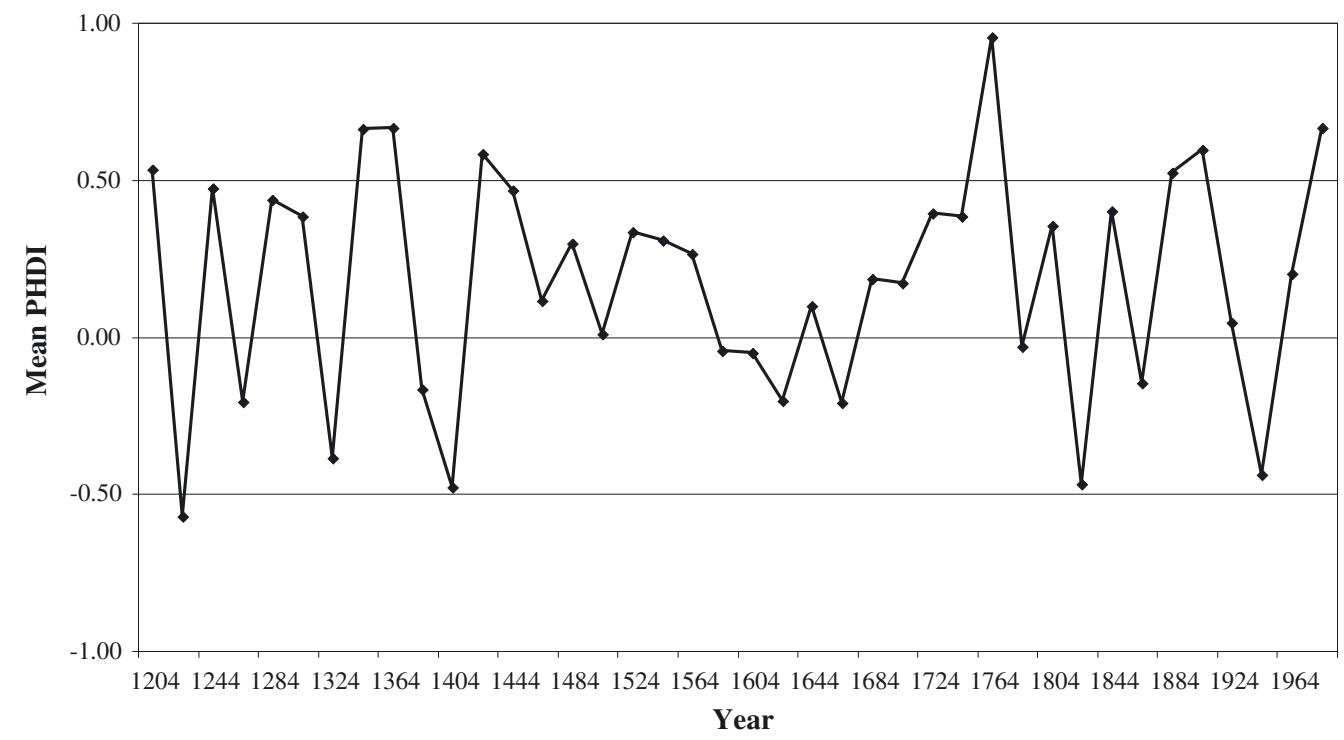

Fig. 3. July PHDI (1185 to 1984) 20 yr means. The year shown corresponds to the last year of the 20 values that were averaged. For example, the first point on the graph corresponds to the mean July PHDI from 1185 to 1204 and the last point corresponds to the mean from 1965 to 1984

800 yr. The period from 1185 to 1424 exhibited substantial interdecadal variability, but little trend in moisture conditions. The period from 1205 to 1224 was the driest 20 yr period ever recorded. After 1424, there is evidence of a protracted period of declining moisture availability (trend towards drier growing-season moisture conditions). Not only were growing seasons becoming drier between 1424 and 1664, but there was also a significant reduction in moisture variability (at least multidecadal variability). After 1664, there was a trend towards wetter growing-season moisture conditions that peaked in 1764 and this $100 \mathrm{yr}$ period also showed reduced multidecadal moisture variability. The period from 1745 to 1764 was the wettest $20 \mathrm{yr}$ period recorded and, not surprisingly, a number of the wettest growing seasons ever recorded occurred during this period. Between 1765 and 1864, there was a trend towards drier growing-season moisture conditions and there was also an increase in multidecadal variability.

During the 20th century a number of distinct moisture regimes occurred. The first $20 \mathrm{yr}$ period from 1905 to 1924 experienced near normal moisture conditions. However, conditions were much drier between 1925 and 1944, and this $20 \mathrm{yr}$ period is one of the driest observed since 1185. Between 1945 and 1964 conditions were slightly wetter than normal and this trend towards wetter growing-season moisture conditions continued during 1965 to 1984. Although the reconstructed record stops in 1984, if the last 19 years of data were included (1985 to 2003), it would show that this period has experienced conditions that were slightly drier than normal. This is due, in part, to the droughts of $1985,1986,1999$, and 2002.

\subsection{How extreme were the growing-season moisture anomalies of 2002 and 2003 ?}

According to the instrumental record, the PHDI in July 2002 was -3.03 , making it the third driest growing season since 1895. However, to put this event into proper perspective, we need to examine how often an extreme event of this magnitude occurred between 1185 and 1984. Because the tree-ring data is only available until 1984, it is impossible to directly compare the instrumental PHDI in July 2002 with the reconstructed PHDI. A linear regression equation was derived using the entire period of overlap between the 2 data sets (1895 to 1984) (Fig. 4). The regression equation ( $\mathrm{r}=$ 0.58) was then used to estimate reconstructed PHDI values for the growing seasons from 1985 to 2003 (Table 9). The regression model predicted that the reconstructed PHDI for July 2002 was -1.42, but given the limited amount of variance accounted for by the model it was deemed appropriate to determine the

Table 9. Summary of the linear regression between the instrumental and reconstructed July PHDI (1895 to 1984)

\begin{tabular}{|lcccc|}
\hline PHDI & $\mathrm{r}$ & $\mathrm{r}^{2}$ & Intercept & Slope \\
\hline July (1895-1984) & 0.58 & 0.33 & 0.001 & 0.432 \\
\hline
\end{tabular}




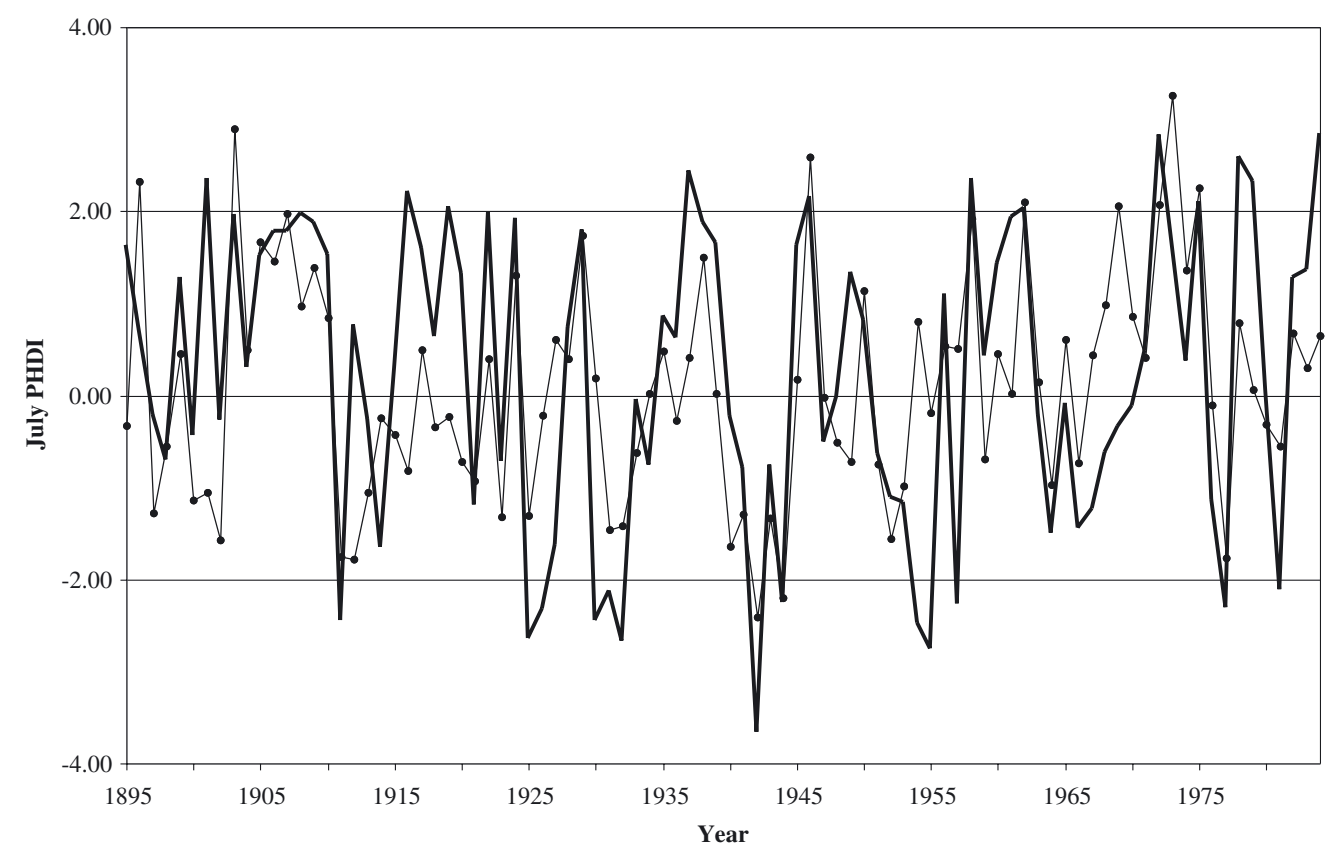

Fig. 4. Reconstructed (•) and instrumental (-) July PHDI (1895-1984)

sampling distribution (or accuracy) of the estimate. The non-parametric bootstrap was used to determine the sampling distribution by randomly generating 1000 samples (or replicates) from the original data set (the instrumental and reconstructed data (1895 to 1984) (Efron \& Tibshirani 1993). A regression model was constructed for each of the 1000 replicates and was used to predict the reconstructed PHDI values for 2002 and 2003. A $95 \%$ confidence interval was generated from the distribution of predicted values for $2002(-0.84$, $-1.78)$ and $2003(1.25,2.39)$. The lower boundary of the $95 \%$ confidence interval for $2002(-1.78)$ was adopted because it provides a more conservative (cautious) estimate of the frequency of moisture anomalies of this magnitude than the original prediction (-1.42). An examination of the $800 \mathrm{yr}$ PHDI record revealed that a drought with a PHDI of at least -1.78 occurred during 48 growing seasons between 1185 and 1984. Thus, the average return period for a drought of this magnitude is approximately $17 \mathrm{yr}$. These results should be interpreted cautiously since they are based on a 'best estimate' of the reconstructed PHDI value.

The same methodology was repeated for the anomalously wet summer of 2003. According to the instrumental record, 2003 was the wettest growing season on record (PHDI $=4.16)$. The corresponding reconstructed PHDI for July 2003 is approximately 1.79 . Again, a more conservative PHDI value (2.39) was adopted based on the upper boundary of the $95 \%$ confidence interval. An examination of the $800 \mathrm{yr}$ record revealed that there were 53 growing seasons with moisture conditions at least as wet as those experienced during 2003. This corresponds to an average return period of approximately $15 \mathrm{yr}$.

Although the severity of the growing-season moisture anomalies in 2002 and 2003 are not particularly unusual when evaluated against the 800 yr record, what is unusual is that these 2 events occurred in consecutive years. According to the reconstructed PHDI, the difference between moisture conditions in 2002 and 2003 represents the 12 th largest change in consecutive growing seasons since 1185.

\section{CONCLUSIONS}

Our current understanding of drought vulnerability is based almost exclusively on climate variability observed during the 20th century. The inclusion of paleoclimatic data in this study provides a more complete picture of growing-season moisture variability in the southern mid-Atlantic region of the USA. The results indicate that this region has experienced significant moisture variability (interannual to multidecadal) over the last $800 \mathrm{yr}$.

Anomalously dry growing seasons (those with a PHDI value at least 1 SD below the mean) have a return period of approximately $6.3 \mathrm{yr}$ and anomalously wet growing seasons have a return period of approximately 6.6 yr. While the majority of wet and dry anomalies are 1 yr events, dry anomalies are slightly more likely to occur in multi-year episodes. However, the 
most extreme wet events tend to be more severe than the most extreme dry events. The 18th century was the wettest century during the last $800 \mathrm{yr}$ and the 16th century was the driest. Conditions during the 18th century were much wetter than they are today, and 5 of the 10 wettest years occurred in the 1700s. The droughts that occurred during the 16th century tended to be both longer and more severe than those of today. The growing-season drought of 1587 was the most severe since 1185 and extended drought events occurred between 1566-1569 and 1576-1579. The recent growingseason moisture anomalies that occurred during 2002 and 2003 can only be considered rare events if they are evaluated with respect to the relatively short instrumental record (1895 to 2003). When these 2 events are compared to the $800 \mathrm{yr}$ reconstructed record, neither is particularly unusual. Therefore, it would be prudent for water resource managers, state and federal emergency management agencies, and those with agricultural interests to be prepared for the recurrence of severe moisture anomalies of this magnitude. Although climate models predict decreases in summer precipitation and significant increases in the frequency and duration of extreme droughts, the data indicate that growing-season moisture conditions during the 20th century (and even the last $19 \mathrm{yr}$ ) appear to be near normal (well within the range of natural climate variability) when compared to the 800 yr record.

Acknowledgements. I would like to thank D. Leathers and D. Legates for commenting on earlier versions of this manuscript and the 3 reviewers for their constructive feedback.

\section{LITERATURE CITED}

Alley WM (1984) The Palmer Drought Severity Index: limitation and assumptions. J Clim Appl Meteorol 23:1100-1109

Cook E, Meko DM, Stockton CW (1997) A new assessment of possible solar and lunar forcing of the bidecadal drought rhythm in the western United States. J Clim 10: 1343-1356

Cook ER, Meko DM, Stahle DW, Cleaveland MK (1999) Drought reconstructions for the continental United States. J Clim 12:1145-1162

deMenocal PB (2001) Cultural responses to climate change during the late Holocene. Science 292:667-673

Druckenbrod DL, Mann M, Stahle DW, Cleaveland MK,

Editorial responsibility: Robert Davis,

Charlottesville, Virginia, USA
Therrell MD, Shugart HH (2003) Late-eighteenth-century precipitation reconstructions from James Madison's Montpelier plantation. Bull Am Meteorol Soc 84:57-71

Efron B, Tibshirani RJ (1993) An introduction to the bootstrap. Chapman \& Hall, New York

Fye FK, Stahle DW, Cook ER (2003) Paleoclimatic analogs to twentieth-century moisture regimes across the United States. Bull Am Meteorol Soc 84:901-909

Gregory JM, Mitchell JFB, Brady AJ (1997) Summer drought in the northern midlatitudes in a time-dependent $\mathrm{CO}_{2}$ climate experiment. J Clim 10:662-686

Guttman NB (1998) Comparing the Palmer Drought Index and the Standardized Precipitation Index. J Am Water Resources Assoc 34:113-121

Heim RR (2002) A review of twentieth century drought indices used in the United States. Bull Am Meteorol Soc 83:1149-1165

Karl T (1986) The sensitivity of the Palmer Drought Severity Index and Palmer's Z-Index to their calibration coefficients including potential evapotranspiration. J Clim Appl Meteorol 25:77-86

Laird KR, Fritz SC, Maasch KA, Cumming BF (1996) Greater drought intensity and frequency before AD 1200 in the Northern Great Plains, USA. Nature 384:552-554

Montgomery J (2002) State wants to tighten the tap. The News Journal, August 15, A1 available at:http:// www.delawareonline.com/newsjournal/

NOAA (2002) NOAA reports drought may linger in East; West. NOAA Press Release March 14, Washington, DC; available at:http://www.publicaffairs.noaa.gov/release2002/mar02/ noaa02025.html

Palmer WC (1965) Meteorological drought. Research Paper no. 45, US Weather Bureau, Washington, DC

Stahle DW, Cleaveland MK, Blanton DB, Therrell MD, Gay DA (1998) The Lost Colony and Jamestown droughts. Science 280:564-567

Stahle DW, Cook ER, Cleaveland MK, Therrell MD, Meko DM, Grissino-Mayer HD, Watson E, Luckman BH (2000) Tree-ring data document 16th century megadrought over North America. EOS 81:124-125

Stockton CW, Meko DM (1983) Drought recurrence in the Great Plains as reconstructed from long-term tree-ring records. J Clim Appl Climatol 22:17-29

Voss R, May W, Roeckner E (2002) Enhanced resolution modelling study on anthropogenic climate change: changes in extremes of the hydrological cycle. Int J Climatol 22: 755-777

Watson T, Overberg P (2002) Storms wash drought out of East Coast. USA Today, November 22, 15A-16A

Woodhouse CA, Overpeck JT (1998) 2000 years of drought variability in the central United States. Bull Am Meteorol Soc 79:2693-2714

Woodhouse CA, Lukas JJ, Brown PM (2002) Drought in the western Great Plains, 1845-56. Bull Am Meteorol Soc 83: $1485-1493$

Submitted: February 10, 2004; Accepted: July 6, 2004

Proofs received from author(s): July 22, 2004 